\title{
Fangia hongkongensis gen. nov., sp. nov., a novel gammaproteobacterium of the order Thiotrichales isolated from coastal seawater of Hong Kong
}

Correspondence

Ken W. K. Lau

sslwk@cuhk.edu.hk

\author{
Ken W. K. Lau, ${ }^{1}$ Jianping Ren, ${ }^{1}$ Ming-Chiu Fung, ${ }^{2}$ Patrick C. Y. Woo, ${ }^{3}$ \\ Kwok-Yung Yuen, ${ }^{3}$ Kelvin K. M. Chan, ${ }^{2}$ Pei-Yuan Qian, ${ }^{1}$ Po-Keung Wong ${ }^{2}$ \\ and Madeline $\mathrm{Wu}^{1}$
}
${ }^{1}$ Department of Biology, The Hong Kong University of Science and Technology, Clear Water Bay, Kowloon, Hong Kong SAR, China
${ }^{2}$ Department of Biology, The Chinese University of Hong Kong, Shatin, NT, Hong Kong SAR, China
${ }^{3}$ Department of Microbiology, Faculty of Medicine, The University of Hong Kong, Queen Mary Hospital Compound, Pokfulam Road, Hong Kong SAR, China

\begin{abstract}
A Gram-negative, coccobacillus-shaped, aerobic bacterium, designated strain UST040201-002 ${ }^{\top}$, was isolated in February 2004 from seawater at the outlet of a sandfilter in Port Shelter, Hong Kong SAR, China. This strain possessed ubiquinone-8; its 16S rRNA gene sequence shared only $91 \%$ similarity with the sequence from Caedibacter taeniospiralis and 89-90\% similarity with sequences from Francisella tularensis, Francisella novicida, Francisella philomiragia and Wolbachia persica. 16S rRNA gene sequence analysis showed that the strain formed a distinct clade with C. taeniospiralis. This subcluster formed a tight coherent group with members of the family Francisellaceae and W. persica. Combined phylogenetic and physiological data suggest that strain UST040201-002 ${ }^{\top}$ represents a novel genus and species within the order Thiotrichales. The name Fangia hongkongensis gen. nov., sp. nov. is proposed;

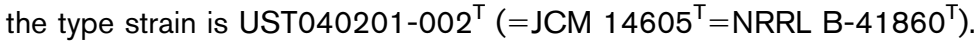

During a study of the diversity of marine bacteria in coastal seawater of Hong Kong, a pale-yellow-pigmented bacterium, UST040201-002 ${ }^{\mathrm{T}}$, was isolated and analysed using a polyphasic taxonomic approach.

Seawater was sampled in February 2004 from the outlet of a tank storing sand-filtered seawater that was pumped from a depth of $5 \mathrm{~m}$ adjacent to the Coastal Marine Laboratory of Hong Kong University of Science and Technology. Aliquots of $100 \mu \mathrm{l}$ were spread onto YPS-SW agar (Lau et al., 2005) and incubated at $30{ }^{\circ} \mathrm{C}$ for 3 days. A pale yellow colony was selected and purified by repeated restreaking on YPS-SW agar. It was cultivated in marine broth $2216(\mathrm{MB})$ and stored in $\mathrm{MB}$ supplemented with $50 \%(\mathrm{v} / \mathrm{v})$ glycerol at $-80{ }^{\circ} \mathrm{C}$.

Colony morphology was observed on YP-SW (YPS-SW without starch) agar plates that had been incubated at $30{ }^{\circ} \mathrm{C}$ for 3 days. Cell morphology was examined using a Zeiss MC100 Spot microscope at $1000 \times$ magnification. Cell motility was determined in motility agar $[0.5 \%$ marine

The GenBank/EMBL/DDBJ accession number for the 16S rRNA gene sequence of UST040201-002 ${ }^{\top}$ is AB176554.

Photomicrographs of strain UST040201-002 ${ }^{\top}$ are available as a supplementary figure with the online version of this paper. agar (MA) with $0.005 \%$ 2,3,5-triphenyltetrazolium chloride]. Gram-reaction was assessed according to Collins et al. (1989). Growth was evaluated at various temperatures (4, $16,20,25,30,33,37,40$ and $42{ }^{\circ} \mathrm{C}$ ) in YP-SW medium (Lau et al., 2005). Growth at various $\mathrm{pH}$ values (3.0-9.0 in single unit steps) was evaluated in artificial seawater (ASW; Lewin \& Lounsbery, 1969) containing $0.1 \%$ yeast extract and buffered with $10 \mathrm{mM}$ sodium acetate (pH 3.0-4.0), $10 \mathrm{mM}$ MES (pH 5.0-6.0) or $10 \mathrm{mM}$ Tris/HCl (pH 7.09.0). $\mathrm{pH}$ values of the media were measured before and after autoclaving and only slight changes of $0.0-0.2$ units were observed. Salinity requirements were determined in YP-SW prepared with $0,5,15,20,40,75$ or $100 \%$ filtered seawater. Salt tolerance was tested in ASW containing $0.4 \%$ yeast extract plus $0,1,2,3,4,5,7.5,10$ or $15 \%(\mathrm{w} / \mathrm{v})$ $\mathrm{NaCl} . \mathrm{NaCl}$ and $\mathrm{KCl}$ requirements were tested in a medium containing $0.1 \%$ yeast extract supplemented with $\mathrm{NaCl}$ or $\mathrm{KCl}$ at $0,0.2,0.4,0.6,0.8$ or $1.0 \%$. The requirement for magnesium ions was tested in ASW with $0.2 \%$ yeast extract, with magnesium sulfate replaced by equimolar levels of potassium sulfate. Anaerobic growth was examined in the Oxoid anaerobic system on YP-SW agar supplemented with $0.1 \% \mathrm{NaNO}_{3}, 0.1 \%$ glucose or $0.1 \%$ meat extract. Acid production from glucose, sucrose, mannose, maltose and lactose was determined in 
Leifson's modified $\mathrm{O} / \mathrm{F}$ medium with $0.1 \%$ cysteine- $\mathrm{HCl}$ (Smibert \& Krieg, 1994). Carbohydrate assimilation was determined with API $50 \mathrm{CH}$ strips using ASW supplemented with $0.05 \%$ yeast extract for 2 weeks at $30{ }^{\circ} \mathrm{C}$. Fermentation of (+)-D-glucose, (-)-D-mannitol and sucrose, and hydrolysis of chitin and Tweens 20, 40, 60 and 80 were carried out according to Baumann \& Baumann (1981). Catalase, oxidase, lecithinase (observed after 2 weeks) and nitrate reductase activities, indole production, $\mathrm{H}_{2} \mathrm{~S}$ generation from cysteine or thiosulfate, and hydrolysis of casein, cellulose, starch and gelatin were performed according to Smibert \& Krieg (1994). DNA hydrolysis was performed according to Lau et al. (2005). Haemolytic activity was investigated using defibrinated rabbit blood $(5 \%, \mathrm{v} / \mathrm{v})$ prepared with blood agar base (BBL) dissolved in filtered seawater. Degradation of dead yeast cells was tested on VY/2 agar (Reichenbach, 1989) prepared with $100 \%$ filtered seawater. Other biochemical characteristics were determined with the API ZYM, API 20E, VITEK ANI and VITEK NHI systems (bioMérieux). Isoprenoid quinone analysis was performed by the HPLC method (Collins, 1994) using ubiquinone-8 extracted from Escherichia coli (strain XL1 Blue) as a reference. Fatty acid methyl ester analysis was determined by the MIDI Sherlock Microbial Identification System (Microbial ID) with cells grown on heart-infusion blood agar supplemented with $3 \% \mathrm{NaCl}$ at $35{ }^{\circ} \mathrm{C}$ for $24 \mathrm{~h}$. Genomic DNA was extracted using a TaKaRa MiniBEST Bacterial Genomic DNA Extraction kit and DNA base composition was determined by using the HPLC method (Mesbah et al., 1989). The $16 \mathrm{~S}$ rRNA gene was amplified using the primer pair 27F (5'AGAGTTTGATCCTGGCTCAG-3') and 1525R (5'-AAGGAGTGWTCCARCC-3') (Lane, 1991) with Vent DNA polymerase (NEB) and sequenced using an Applied Biosystems 3100 automated DNA sequencer. Related 16S rRNA gene sequences were retrieved from the NCBI nucleotide database after searching with BLAST (Altschul et al., 1997). The sequences of strain UST040201-002 ${ }^{\mathrm{T}}$ and related species were aligned with CLUSTAL_X (Thompson et al., 1997) and edited with the BioEdit sequence alignment editor V5.0.9 (Hall, 1999; www.mbio.ncsu.edu/ BioEdit/bioedit.html). 16S rRNA gene sequence similarity values were calculated with 1255 aligned nucleotides, after removal of columns containing gaps or ambiguous nucleotides [positions 29-1419; Escherichia coli numbering (Brosius et al., 1978)], using BioEdit. Evolutionary distances were computed using the Kimura two-parameter model (Kimura, 1980) and phylogenetic trees were generated by MEGA version 2.1 (Kumar et al., 2001) using the neighbour-joining method (Saitou \& Nei, 1987) or the minimum-evolution algorithm and evaluated by bootstrap analyses (Felsenstein, 1985) based on 1000 resamplings.

At $30{ }^{\circ} \mathrm{C}$, strain UST040201-002 ${ }^{\mathrm{T}}$ grew on MA, YP-SW agar, heart-infusion agar with $5 \%$ rabbit blood (HIAB; prepared with or without filtered seawater) and medium with $2.5 \% \mathrm{KCl}$ or $\mathrm{NaCl}$ plus $0.1 \%$ yeast extract, but not on nutrient agar. At $25{ }^{\circ} \mathrm{C}$, the bacterium grew on horse blood agar and chocolate agar, but not MacConkey agar. It did not grow on blood agar, chocolate agar or MacConkey agar, with or without $\mathrm{CO}_{2}$, at $37{ }^{\circ} \mathrm{C}$. Colonies were $0.5-$ $2.0 \mathrm{~mm}$ in diameter, pale yellow, circular, convex, smooth, glistening, translucent and mucoid with entire margins on YP-SW after 3 days incubation at $30{ }^{\circ} \mathrm{C}$. On horse blood agar or chocolate agar, colonies appeared grey in colour. On HIAB agar (prepared in seawater), $\alpha$-haemolysis was observed after 4 days incubation at $30{ }^{\circ} \mathrm{C}$. In $\mathrm{MB}$ overnight cultures, cells of strain UST040201-002 ${ }^{\mathrm{T}}$ were short rods or coccobacilli $(0.35-0.70 \times 0.70-1.50 \mu \mathrm{m})$, occurring singly

\section{Table 1. Phenotypic characteristics of strain UST040201- $002^{\top}$}

Positive for alkaline phosphatase, esterase (C4, C8), lipase, leucine arylamidase, proline arylamidase, $\gamma$-glutamyl arylamidase, acid phosphatase, naphthol-AS-Bl-phosphorylase, $\beta$-galactosidase, $N$ acetyl- $\beta$-glucosaminidase, tryptophan deaminase, reduction of triphenyl tetrazolium and reduction of resazurin. Negative for valine/ cystine arylamidase, trypsin, $\alpha$-chromotrypsin, $\alpha$-galactosidase, $\beta$ glucuronidase, $\alpha$-glucosidase, $\beta$-glucosidase, $\alpha$-mannosidase, $\alpha$-fucosidase, arginine dihydrolase, lysine decarboxylase, ornithine decarboxylase, urease and the Voges-Proskauer test. Produces acid from glucose, sucrose and maltose. Does not assimilate glycerol, erythritol, D-arabinose, L-arabinose, D-ribose, D-xylose, L-xylose, D-adonitol, methyl $\beta$-D-xylopyranoside, D-galactose, D-glucose, D-fructose, Dmannose, L-sorbose, L-rhamnose, dulcitol, inositol, D-mannitol, Dsorbitol, methyl $\alpha$-D-mannopyranoside, methyl $\alpha$-D-glucopyranoside, $\mathrm{N}$-acetylglucosamine, amygdalin, arbutin, aesculin, ferric citrate, salicin, D-cellobiose, maltose, D-lactose, D-melibiose, sucrose, trehalose, inulin, D-melezitose, D-raffinose, glycogen, xylitol, gentiobiose, turanose, D-lyxose, D-tagatose, D-fucose, L-fucose, D-arabitol, L-arabitol, potassium gluconate, potassium 2-ketogluconate or potassium 5ketogluconate. + , Positive; - , negative; $\mathrm{w}+$, weakly positive.

\begin{tabular}{|lc|}
\hline Characteristic & UST040201-002 $^{\mathbf{T}}$ \\
\hline Salinity range (\% seawater) & $15-100$ \\
Oxidase & $\mathrm{W}$ \\
Catalase & + \\
Denitrification & - \\
Lecithinase & + \\
Hydrolysis of: & \\
Agar & - \\
Casein & + \\
Cellulose & - \\
Chitin & - \\
DNA & + \\
Aesculin & - \\
Gelatin & + \\
Starch & - \\
Tween $20,40,60,80$ & + \\
Production of: & \\
$\quad \mathrm{H}_{2} S$ from cysteine or thiosulfate & - \\
Indole & - \\
Haemolysis in rabbit blood agar & + \\
Hydrolysis of dead yeast cells & - \\
\hline
\end{tabular}


Table 2. Whole-cell fatty acid profiles of strain UST040201$002^{\top}$ and species of the genus Francisella

Taxa: 1, strain UST040201-002 ${ }^{\mathrm{T}} ; 2$, F. tularensis/F. novicida (14 strains); 3, F. philomiragia (16 strains). Values given are percentages of total fatty acids. Values in parentheses indicate the range. Fatty acids are designated as total number of carbon atoms: number of double bonds, followed by the position of the double bond from the aliphatic end of the molecule; i, a and $\mathrm{OH}$ represent iso-branched, anteiso-branched and hydroxy fatty acids, respectively. Data are from this study and Hollis et al. (1989). Strain UST040201-002 ${ }^{\mathrm{T}}$ was grown on $\mathrm{HIAB}+3 \% \mathrm{NaCl}$ at $35{ }^{\circ} \mathrm{C}$ for $24 \mathrm{~h}$. Other strains were grown on $\mathrm{HIAB}$ at $35{ }^{\circ} \mathrm{C}$ for $24 \mathrm{~h}$ (Hollis et al., 1989). $c$ represents a cis isomer. ECL, Equivalent chain-length; tr, less than $0.8 \%$.

\begin{tabular}{|c|c|c|c|}
\hline Fatty acid & 1 & 2 & 3 \\
\hline \multicolumn{4}{|l|}{ Saturated straight-chain } \\
\hline $10: 0$ & - & $30(10-58)$ & $13(10-58)$ \\
\hline $12: 0$ & - & $\operatorname{tr}(0-1)$ & $\operatorname{tr}(0-1)$ \\
\hline $14: 0$ & $\operatorname{tr}$ & $11(4-15)$ & $16(8-25)$ \\
\hline $16: 0$ & 2.9 & $10(5-13)$ & $9(6-15)$ \\
\hline 16:0 aldehyde & - & $1(0-4)$ & $2(0-5)$ \\
\hline $17: 0$ & $\operatorname{tr}$ & - & - \\
\hline $18: 0$ & 4.7 & $3(1-4)$ & $9(6-13)$ \\
\hline $19: 0$ & $\operatorname{tr}$ & - & - \\
\hline $20: 0$ & $\operatorname{tr}$ & $1(0-3)$ & $3(2-4)$ \\
\hline $22: 0$ & - & $5(3-10)$ & $6(4-8)$ \\
\hline $24: 0$ & - & $5(0-10)$ & $4(0-9)$ \\
\hline $26: 0$ & - & $\operatorname{tr}(0-1)$ & $\operatorname{tr}(0-1)$ \\
\hline \multicolumn{4}{|l|}{ Saturated branched-chain } \\
\hline $\mathrm{a}-15: 0$ & 19.0 & - & - \\
\hline $\mathrm{a}-17: 0$ & 25.1 & - & - \\
\hline$a-19: 0$ & 3.7 & - & - \\
\hline $\mathrm{i}-14: 0$ & 3.9 & - & - \\
\hline $\mathrm{i}-15: 0$ & $\operatorname{tr}$ & - & - \\
\hline$i-16: 0$ & - & - & - \\
\hline $17: 0$ 10-methyl & $\operatorname{tr}$ & - & - \\
\hline $\mathrm{i}-17: 0$ & $\operatorname{tr}$ & - & - \\
\hline $\mathrm{i}-18: 0$ & 3.0 & - & - \\
\hline \multicolumn{4}{|l|}{ Unsaturated/hydroxy } \\
\hline $13: 1$ AT $12-13$ & $\operatorname{tr}$ & - & - \\
\hline $18: 1 \omega 9 c$ & 7.9 & $7(4-8)$ & $12(9-17)$ \\
\hline $18: 2$ & - & $2(0-3)$ & $2(1-3)$ \\
\hline $20: 1$ & - & $\operatorname{tr}(0-1)$ & $\operatorname{tr}(0-1)$ \\
\hline $22: 1$ & - & $1(0-2)$ & $1(1-2)$ \\
\hline $24: 1$ & - & $5(0-8)$ & $9(5-14)$ \\
\hline $26: 1$ & - & $\operatorname{tr}(0-1)$ & $\operatorname{tr}(0-2)$ \\
\hline $10: 02-\mathrm{OH}$ & - & $1(0-4)$ & $\operatorname{tr}(0-1)$ \\
\hline $10: 03-\mathrm{OH}$ & $\operatorname{tr}$ & - & - \\
\hline $12: 02-\mathrm{OH}$ & $\operatorname{tr}$ & - & - \\
\hline $12: 03-\mathrm{OH}$ & 3.5 & - & - \\
\hline $\mathrm{i}-14: 03-\mathrm{OH}$ & $\operatorname{tr}$ & - & - \\
\hline $15: 02-\mathrm{OH}$ & $\operatorname{tr}$ & - & - \\
\hline $16: 03-\mathrm{OH}$ & 0.8 & $3(0-6)$ & $3(2-4)$ \\
\hline $\mathrm{i}-16: 03-\mathrm{OH}$ & 0.9 & - & - \\
\hline $17: 03-\mathrm{OH}$ & $\operatorname{tr}$ & - & - \\
\hline $18: 03-\mathrm{OH}$ & 1.4 & $12(7-24)$ & $9(6-11)$ \\
\hline $14: 03-\mathrm{OH} / 16: 1$ ISO I & 5.5 & - & - \\
\hline \multicolumn{4}{|l|}{ Unknown } \\
\hline ECL 10.928 & 1.0 & - & - \\
\hline
\end{tabular}

\begin{tabular}{|llll|}
\hline Fatty acid & $\mathbf{1}$ & $\mathbf{2}$ & $\mathbf{3}$ \\
\hline ECL 12.484 & $\operatorname{tr}$ & - & - \\
ECL 14.502 & $\operatorname{tr}$ & - & - \\
ECL 14.959 & 1.0 & - & - \\
ECL 15.669 & $\operatorname{tr}$ & - & - \\
\hline
\end{tabular}

or in pairs. In the stationary phase, spherical cells (2.5$5.7 \mu \mathrm{m})$ were occasionally seen. Cells were non-motile. No flagella were observed when cells were stained with $1 \%$ phosphotungstic acid and examined by TEM. Colony morphology and phase-contrast and SEM micrographs are available as Supplementary Fig. S1a-c in IJSEM Online. Strain UST040201-002 ${ }^{\mathrm{T}}$ was mesophilic and grew at 16$40{ }^{\circ} \mathrm{C}$ with optimal growth at $30-33{ }^{\circ} \mathrm{C}$. It grew at $\mathrm{pH} 5.0-$ 8.8, with optimal growth around $\mathrm{pH} 4.9-6.8$. The strain required either $\mathrm{Na}^{+}$or $\mathrm{K}^{+}$, but not $\mathrm{Mg}^{2+}$, for growth. It grew in $0.4-7.5 \%(\mathrm{w} / \mathrm{v}) \mathrm{NaCl}$, with optimal growth between 2 and $3 \%(\mathrm{w} / \mathrm{v}) \mathrm{NaCl}$. The minimum amount of $\mathrm{KCl}$ that supported growth was about $0.6 \%$. The isoprenoid quinone of strain UST040201-002 ${ }^{\mathrm{T}}$ was ubiquinone- 8 . The DNA G + C content of strain UST040201-002 ${ }^{\mathrm{T}}$ was $53.9 \pm 0.4 \mathrm{~mol} \%$. Table 1 lists the phenotypic characteristics of strain UST040201-002 ${ }^{\mathrm{T}}$ that were analysed.

The fatty acid profile of strain UST040201-002 ${ }^{\mathrm{T}}$ was very different from those of other members of the genus Francisella (Table 2). Strain UST040201-002 ${ }^{\mathrm{T}}$ contained a$17: 0, \mathrm{a}-15: 0,18: 1 \omega 9 c$ and $14: 03-\mathrm{OH} / 16: 1$ ISO I as major fatty acids, whereas members of the genus Francisella contained 10:0, 14:0, 16:0, 18:0, 18:0 3-OH and $18: 1 \omega 9 c$ as major fatty acids.

The nearly complete 16S rRNA gene sequence of strain UST040201-002 ${ }^{\mathrm{T}}$ (1515 nt positions) shared only $91 \%$ similarity with that of the type strain of Caedibacter taeniospiralis, an obligate intracellular parasite of Paramecium tetraurelia stock 51k (Beier et al., 2002) and 89$90 \%$ similarity with Francisella tularensis subsp. tularensis (Olsufiev et al., 1959; Larsson et al., 2005), Francisella tularensis subsp. mediasiatica and Francisella tularensis subsp. holarctica (Olsufjev \& Mescheryakova, 1983), and Francisella novicida and Francisella philomiragia (Hollis et al., 1989). The 16S rRNA gene sequence of strain UST040201-002 $2^{\mathrm{T}}$ shared similarities of only $84-85 \%$ and 83-84\% with members of the families Piscirickettsiaceae and Thiotrichaceae, respectively.

Phylogenetic analysis using the neighbour-joining algorithm showed that strain UST040201-002 ${ }^{\mathrm{T}}$ formed a distinct lineage within the order Thiotrichales and clustered with C. taeniospiralis with a $100 \%$ bootstrap value; this clade was coherently linked to the lineage of Francisellaceae at $100 \%$ bootstrap value (Fig. 1). This tight coherent clustering of strain UST040201-002 ${ }^{\mathrm{T}}$ with C. taeniospiralis and members of the family Francisellaceae was confirmed in phylogenetic trees generated from minimum-evolution or maximum-parsimony algorithms (data not shown) and agreed with the findings of Beier et al. (2002) that $C$. 


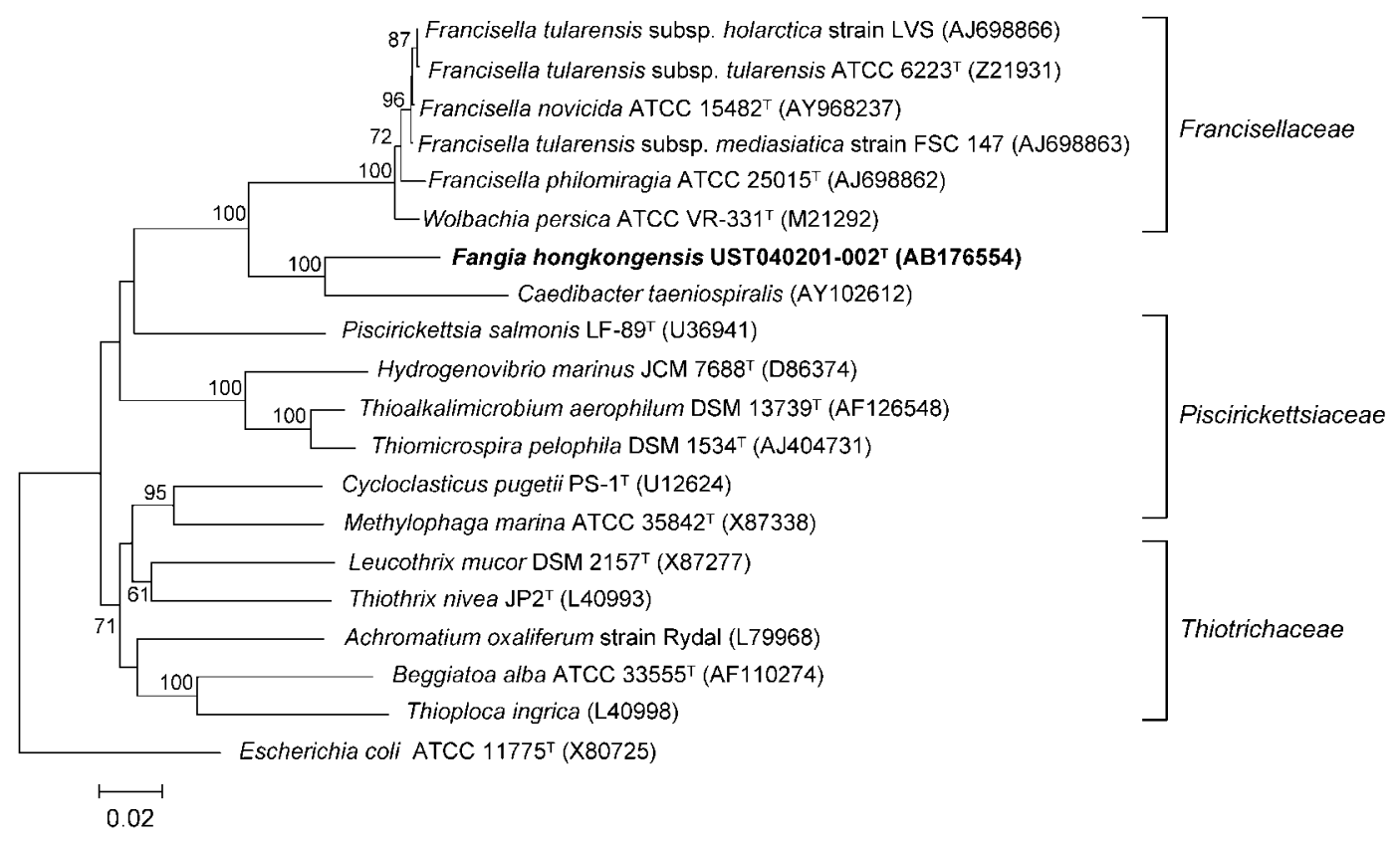

Fig. 1. Phylogenetic relationship between strain UST040201-002 ${ }^{\top}$ and related taxa within the order Thiotrichales based on 16S rRNA gene sequences. The tree was created by using the neighbour-joining method; numbers at nodes represent bootstrap percentages from 1000 resampled datasets. Escherichia coli ATCC $11775^{\top}$ (GenBank accession no. X80725) was used as the outgroup. Bar, 0.02 nt substitutions per position.

taeniospiralis is closely affiliated with members of the family Francisellaceae.

Strain UST040201-002 ${ }^{\mathrm{T}}$ shared many common phenotypic traits with members of the family Francisellaceae: Gramnegative, short rod or coccobacilli morphology, aerobic metabolism, catalase activity, lack of flagella and spores, ability to form acid from glucose but not from lactose, $\beta$ lactamase-positive, urease-negative, and susceptible to tetracycline and chloramphenicol. However, strain UST040201-002 ${ }^{\mathrm{T}}$ differed from current members of the genus Francisella by its higher $\mathrm{G}+\mathrm{C}$ content and its inability to produce $\mathrm{H}_{2} \mathrm{~S}$ from cysteine (Table 3). In particular, strain UST040201-002 ${ }^{\mathrm{T}}$ could be distinguished from $F$. tularensis/ $F$. novicida by its production of oxidase and gelatinase and from $F$. philomiragia by its inability to produce indole. On the basis of all characteristics described above, it is proposed that strain UST040201-002 ${ }^{\mathrm{T}}$ be placed in a new genus in the order Thiotrichales as a representative of a novel species, Fangia hongkongensis gen. nov., sp. nov.

\section{Description of Fangia gen. nov.}

Fangia (Fan'gi.a. N.L. fem. n. Fangia named after Professor Xinfang Fang, founder of the Institute of Microbiology of the Chinese Academy of Sciences).

Gram-negative, short rods to coccobacilli, occurring singly or in pairs, non-motile. Non-sporulating and nonflagellated. Divides by binary fission. Strictly aerobic, chemoheterotrophic, requiring sodium or potassium ions and organic growth factors such as yeast extract for growth. Produces acid from glucose. Catalase-positive; positive or weakly positive for oxidase. Major respiratory quinone is Q-8. Predominant fatty acids are a-17:0, a-15:0 and $18: 1 \omega 9 c$. Phylogenetically, Fangia is a member of the order Thiotrichales. The type species is Fangia hongkongensis.

Table 3. Characteristics that differentiate strain UST040201$002^{\top}$ from related species of the family Francisellaceae

Taxa: 1, strain UST040201-002 $2^{\mathrm{T}} ; 2, F$. tularensis/F. novicida; 3, F. philomiragia. Data are from Sjöstedt (2005) and this study. +, Positive; -, negative; $\mathrm{w}+$, weakly positive; $\mathrm{v}$, variable.

\begin{tabular}{|lccc|}
\hline Characteristic & $\mathbf{1}$ & $\mathbf{2}$ & $\mathbf{3}$ \\
\hline Size $(\mu \mathrm{m})$ & $0.35-0.7 \times 0.7-1.5^{*}$ & $0.2-0.7 \times 0.2$ & $0.7 \times 1.7$ \\
Optimum growth & $30-33$ & 37 & 25 or 37 \\
$\quad$ temperature $\left({ }^{\circ} \mathrm{C}\right)$ & & & \\
Oxidase & $\mathrm{W}$ & - & + \\
Gelatinase & + & - & $\mathrm{V}$ \\
$\mathrm{H}_{2} \mathrm{~S}$ production & - & + & + \\
from cysteine & & - & + \\
Indole production & - & $33-36$ & $33-34$ \\
DNA G+C content & 54 & & \\
$\quad($ mol\%) & & & \\
\hline
\end{tabular}

* Size of bacteria from an overnight MB culture. 


\section{Description of Fangia hongkongensis sp. nov.}

Fangia hongkongensis (hong.kong.en'sis. N.L. fem. adj. hongkongensis pertaining to Hong Kong SAR, PR China, where the bacterium was first isolated).

In addition to the characteristics given in the genus description, exhibits the following properties. In MB, cells are short rods about $0.35-0.70 \mu \mathrm{m}$ in diameter and $0.7-$ $1.5 \mu \mathrm{m}$ in length. In half-strength $\mathrm{MB}$, spherical and pleomorphic cells of $0.6-4.8 \times 0.9-4.8 \mu \mathrm{m}$ are seen. Colonies are circular, pale yellow, translucent, smooth, shiny, convex and mucoid with entire margins. Colonies are about $0.5-2.0 \mathrm{~mm}$ in diameter after 3 days culture on YP-SW agar at $30{ }^{\circ} \mathrm{C}$. Cells are mesophilic. Grows at $16-$ $40{ }^{\circ} \mathrm{C}$ and $\mathrm{pH} 4.9-8.8$, with optimal growth at $30-33{ }^{\circ} \mathrm{C}$ and around $\mathrm{pH}$ 4.9-6.8. Requires sodium or potassium ions for growth. Grows in $0.4-7.5 \%(\mathrm{w} / \mathrm{v}) \mathrm{NaCl}$, with optimal growth at 2-3\%(w/v) $\mathrm{NaCl}$. Physiological and biochemical properties are listed in Table 1. Fatty acid profile is given in Table 2. Resistant to ampicillin $(10 \mu \mathrm{g})$, polymyxin $\mathrm{B}(300 \mathrm{U})$ and penicillin $\mathrm{G}(2 \mathrm{U})$ and sensitive to chloramphenicol $(3 \mu \mathrm{g})$, tetracycline $(30 \mu \mathrm{g})$, streptomycin $(10 \mu \mathrm{g})$, gentamicin sulfate $(10 \mu \mathrm{g})$ and kanamy$\operatorname{cin}(20 \mu \mathrm{g})$.

The type strain is UST040201-002 ${ }^{\mathrm{T}}\left(=\mathrm{JCM} 14605^{\mathrm{T}}=\mathrm{NRRL}\right.$ $\mathrm{B}-41860^{\mathrm{T}}$ ), which was isolated from a seawater sample collected from sand-filtered seawater, in the Port Shelter adjacent to the Coastal Marine Laboratory, Hong Kong University of Science and Technology.

\section{Acknowledgements}

We sincerely thank Professor Hans G. Trüper for valuable suggestions in the etymology, $\mathrm{Mr}$ Stephen Leung for scanning electron microscopy, Dr Xiancui Li for DNA G $+\mathrm{C}$ analysis, Miss Natalie Wai for fatty acid methyl ester analysis and Mr Simon Lau for antibiotic disc-diffusion assays. This work was supported by grants R5498, CMI03/04.SC03, CAs-CF03/04.Sc01 and CA04/ 05.SC01.

\section{References}

Altschul, S. F., Madden, T. L., Schäffer, A. A., Zhang, J., Zhang, Z., Miller, W. \& Lipman, D. J. (1997). Gapped BLAST and PSI-BLAST: a new generation of protein database search programs. Nucleic Acids Res 25, 3389-3402.

Baumann, P. \& Baumann, L. (1981). The marine Gram-negative eubacteria: genera Photobacterium, Beneckea, Alteromonas, Pseudomonas and Alcaligenes. In The Prokaryotes, pp. 1302-1331. Edited by M. P. Starr, H. Stolp, H. G. Trüper, A. Balows \& H. Schlegel. Berlin: Springer-Verlag.

Beier, C. L., Horn, M., Michel, R., Schweikert, M., Gortz, H. D. \& Wagner, M. (2002). The genus Caedibacter comprises endosymbionts of Paramecium spp. related to the Rickettsiales (Alphaproteobacteria) and to Francisella tularensis (Gammaproteobacteria). Appl Environ Microbiol 68, 6043-6050.

Brosius, J., Palmer, M. L., Kennedy, P. J. \& Noller, H. F. (1978). Complete nucleotide sequence of a $16 \mathrm{~S}$ ribosomal RNA gene from Escherichia coli. Proc Natl Acad Sci U S A 75, 4801-4805.
Collins, M. D. (1994). Isoprenoid quinones. In Chemical Methods in Prokaryotic Systematics, pp. 265-309. Edited by M. Goodfellow \& A. G. O'Donnell. Chichester, UK: Wiley.

Collins, C. H., Lyne, P. M. \& Grange, J. M. (1989). Collins and Lyne's Microbiological Methods. London/Boston: Butterworths.

Felsenstein, J. (1985). Confidence limits on phylogenies: an approach using the bootstrap. Evolution 39, 783-791.

Hall, T. A. (1999). BioEdit: a user-friendly biological sequence alignment editor and analysis program for Windows 95/98/NT. Nucleic Acids Symp Ser 41, 95-98.

Hollis, D. G., Weaver, R. E., Steigerwalt, A. G., Wenger, J. D., Moss, C. W. \& Brenner, D. J. (1989). Francisella philomiragia comb. nov. (formerly Yersinia philomiragia) and Francisella tularensis biogroup novicida (formerly Francisella novicida) associated with human disease. J Clin Microbiol 27, 1601-1608.

Kimura, M. (1980). A simple method for estimating evolutionary rates of base substitutions through comparative studies of nucleotide sequences. J Mol Evol 16, 111-120.

Kumar, S., Tamura, K., Jakobsen, I. B. \& Nei, M. (2001). MEGA2: Molecular Evolutionary Genetics Analysis software. Bioinformatics 17, 1244-1245.

Lane, D. J. (1991). 16S/23S rRNA sequencing. In Nucleic Acid Techniques in Bacterial Systematics, pp. 115-175. Edited by E. Stackebrandt \& M. Goodfellow. Chichester, UK: Wiley.

Larsson, P., Oyston, P. C., Chain, P., Chu, M. C., Duffield, M., Fuxelius, H. H., Garcia, E., Halltorp, G., Johansson, D. \& other authors (2005). The complete genome sequence of Francisella tularensis, the causative agent of tularemia. Nat Genet 37, 153-159.

Lau, K. W., Ng, C. Y., Ren, J., Lau, S. C., Qian, P. Y., Wong, P. K., Lau, T. C. \& Wu, M. (2005). Owenweeksia hongkongensis gen. nov., sp. nov., a novel marine bacterium of the phylum 'Bacteroidetes'. Int J Syst Evol Microbiol 55, 1051-1057.

Lewin, R. A. \& Lounsbery, D. M. (1969). Isolation, cultivation and characterization of flexibacteria. J Gen Microbiol 58, 145-170.

Mesbah, M., Premachandran, U. \& Whitman, W. B. (1989). Precise measurement of the $\mathrm{G}+\mathrm{C}$ content of deoxyribonucleic acid by highperformance liquid chromatography. Int J Syst Bacteriol 39, 159-167.

Olsufjev, N. G., Emelyanova, O. S. \& Dunaeva, T. N. (1959). Comparative study of strains of $B$. tularense in the Old and New World and their taxonomy. J Hyg Epidemiol Microbiol Immunol 3, 138-149.

Olsufjev, N. G. \& Meshcheryakova, I. S. (1983). Subspecific taxonomy of Francisella tularensis McCoy and Chapin 1912. Int J Syst Bacteriol 33, 872-874.

Reichenbach, H. (1989). Family 1. Cytophagaceae Stanier 1940, $630^{\mathrm{AL}}$ emend. In Bergey's Manual of Systematic Bacteriology, vol. 3, pp. 2013-2082. Edited by J. T. Staley, M. P. Bryant, N. Pfennig \& J. G. Holt. Baltimore: Williams \& Wilkins.

Saitou, N. \& Nei, M. (1987). The neighbor-joining method: a new method for reconstructing phylogenetic trees. Mol Biol Evol 4, 406-425. Sjöstedt, A. B. (2005). Genus I. Francisella Dorofe'ev 1947, $176^{\mathrm{AL}}$. In Bergey's Manual of Systematic Bacteriology, 2nd edn, vol. 2, part B, pp. 200-210. Edited by D. J. Brenner, N. R. Krieg, J. T. Staley \& G. M. Garrity. New York: Springer.

Smibert, R. M. \& Krieg, N. R. (1994). Phenotypic characterization. In Methods for General and Molecular Bacteriology, pp. 607-654. Edited by P. Gerhardt, R. G. E. Murray, W. A. Wood \& N. R. Krieg. Washington, DC: American Society for Microbiology.

Thompson, J. D., Gibson, T. J., Plewniak, F., Jeanmougin, F. \& Higgins, D. G. (1997). The CLUSTAL_X windows interface: flexible strategies for multiple sequence alignment aided by quality analysis tools. Nucleic Acids Res 25, 4876-4882. 